Jurnal Keuangan dan Perbankan, 22(2):373-379, 2018

http://jurnal.unmer.ac.id/index.php/jkdp

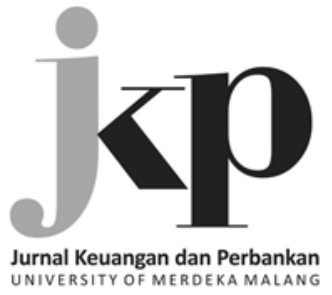

Article history:

Received: 2017-12-26

Revised: 2018-03-26

Accepted: 2018-04-02

\section{Laely Aghe Africa}

Department of Accounting

STIE Perbanas Surabaya

Jl. Nginden Semolo No.34-36

Surabaya, 60118, Indonesia $\square$ Corresponding Author:

Laely Aghe Africa:

Tel. +62 31594 7151/

Fax. +62 315935937

E-mail: laely.aghe@perbanas.ac.id

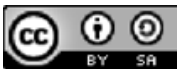

This is an open access

article under the CC-BY-SA license

Laely Aghe Africa (Indonesia)

\title{
Bankometer Models for Predicting Financial Distress in Banking Industry
}

\begin{abstract}
Banking is a collection of several functions of the bank, which focus on profit and on social. However, the banking world can also experience collapse, and there are indications of bankruptcy, and one model for predicting bankruptcy is Bankometer Model. The purpose of this study was to analyze whether Bankometer Model could be used to determine financial distress. The samples of this research were 111 bank data which were listed in Indonesia Stock Exchange from 2014 to 2016. It consisted of 60 data for foreign exchange bank and 51 data for non-foreign exchange bank. Logistic Regression SPSS Version 23 was used to analyze data. The result of this research was that Bankometer Model could be used to determine financial distress for foreign exchange bank and non-foreign exchange bank. The implications of this research were for company management in deciding company policies related to financial distress.
\end{abstract}

Keywords: Bankometer Model; Financial Distress; Foreign Exchange Bank; Non-foreign Exchange Bank

\section{JEL Classification: G31, G32, G34}

Citation: Africa, L. A. (2018). Bankometer model for predicting financial distress on foreign exchange and non-foreign exchange banks. Jurnal Keuangan dan Perbankan, 22(2), 373-379. https://doi.org/10.26905/jkdp.v22i2.2050.

\begin{abstract}
Abstrak
Perbankan merupakan kumpulan dari beberapa fungsi bank, yang fokus pada profit namun juga pada sosial. Namun di dunia perbankan juga dapat mengalami colaps dan ada indikasi kebangkrutan, dan salah satu model untuk memprediksi kebangkrutan adalah dengan Model Bankometer. Tujuan penelitian ini adalah untuk menganalisa apakah Model Bankometer dapat digunakan untuk menentukan financial distress. Sampel dari penelitian ini adalah 111 data bank yang terdaftar di Bursa Efek Indonesia tahun 2014 sampai 2016, 60 data untuk bank devisa dan 51 data untuk bank nondevisa. Regresi Logistic SPSS Versi 23 digunakan untuk menganalisis data. Hasil dari penelitian ini adalah bahwa Model Bankometer dapat digunakan untuk menentukan financial distress untuk bank devisa dan bank non-devisa. Implikasi penelitian ini adalah untuk manajemen perusahaan dalam memutuskan kebijakan perusahaan yang terkait dengan financial distress.
\end{abstract}

Kata Kunci: Bank Devisa; Bank Non Devisa; Financial Distress; Model Bankometer 


\section{Jurnal Keuangan dan Perbankan | PERBANKAN}

Vol. 22, No. 2, April 2018: 373-379

Banking as a complex form of a financial institution has an important role in the movement of the economy both micro and macro scale. Banking sector contributes a lot to the smooth running of all economic activities within a country. Banking acts as a payment facility both domestically and abroad, as a place to secure assets either liquid assets (cash) or non-liquid assets (securities and others that can be stored in the Safe Deposit Box). However, banks can experience collapse. Therefore it needs to be anticipated by a model for predicting financial distress. If the condition is already known from the beginning, then efforts should be made as much as possible so that banks do not experience collapse. Unless anticipated, some banks must be liquidated, restructured and even closed by prevailing Bank Indonesia policies. Based on the data from LPS (saving guarantor institution), there are around 71 banks closed since 2005 until 2016, including 1 Commercial Bank and 70 BPRs. It was because the CAR (Capital Adequacy Ratio) owned by the Bank was minus $209.79 \%$ and the average NPL (Non-Performing Loan) reached $76.18 \%$.

There are previous researches related to the type of financial distress prediction model and some ratios that can be used to predict the condition such as the research conducted by Almilia \& Kristijadi (2003), Fatmawati (2012) and Gunawan, Pamungkas, \& Susilawati (2017). They found that Altman Model, Grover Model, and Zmijewski Model could be used in predicting corporate delisting at IDX and predicting financial distress at manufacturing companies. Samanhyia, Oware, \& Anisom-Yaansah (2016) found that Altman Z-Score Model and Boone indicator could be used to predict financial distress in the banking sector. Africa (2016) found that there was a financial ratio included in the risk analysis that could be used to predict financial distress in a bank go public in Indonesia namely LDR. Kurniawati \& Kholis (2015) found that the accuracy level of the financial distress prediction model in Syariah banking sector was: the first level was the Grover Model, the second level was the Springate
Model, and the third level was the Altman Model. Research by Husein \& Pambekti (2014) found that of the four models of Altman, Springate, Zmijewski, and Grover, the best used in predicting Syariah firms was the Zmijewski model.

The latest prediction model is the Bankometer Model. The research on this model has not been much done, and the samples selected in the form of banking financial statements is still very few. One study was conducted by Laila \& Widihadnanto (2017) on the application of Bankometer Model in Syariah banking and conventional banking. The result showed that Bankometer Model could be applied to predict financial distress in Syariah banking and conventional banking. Between the two firms, there was no difference in the application of the model. According to Budiman, Herwany, \& Kristanti (2017), the use of the Bankometer Model could be used to predict financial distress in Syariah banks.

Several studies have applied the model of Bankometer in various countries, such as in Pakistan by Shar et al. (2010) and Hanif et al. (2012), in Srilanka by Nimalathasan, Balaputhiran \& Priya (2012) and Arulvel \& Balaputhiran (2014), in Macedonia by Popovska (2014) and in Egypt by Fayed (2013). Erari et al. (2013) suggested that Bankometer Model was more appropriate for use in banks than Altman-Z score model, and it is also easier to apply than CAEL model (Capital, Assets, Earnings, Liquidity).

The results of several previous studies were found to be inconsistent, due to the difference in research subjects among researchers despite the same prediction model. Thus, it needs to be reexamined by different research samples or addition of samples and different time periods. The difference of this research from the previous researches lies in the selection of firm samples and the selection of prediction models, in which Grover and Zmijewski's models have already widely used while Bankometer Model has not been examined. In this 
research, the problem described is that the application of Bankometer Model in banking firms in Indonesia is still not widely used especially for foreign exchange and non-foreign exchange banks.

This study aims to analyze Bankometer Model to predict financial distress and compare the application of Bankometer Model on foreign exchange and non-foreign exchange banks in Indonesia.

\section{METHODS}

This research was a kind of quantitative research and used secondary data. The population of this study was foreign exchange banks and non-foreign exchange banks in Indonesia, excluding BPR (People's Financing Bank), BPD (Local Government Bank) and Syariah bank. The research samples were foreign exchange and non-foreign exchange banking firms listed on the Indonesia Stock Exchange (www.idx.go.id) between 2014 and 2016.

The criteria for sampling in this research were that: (1) the banking firms were active in Indonesia Stock Exchange in 2014-2016. (2) They were a foreign exchange and non-foreign exchange banks that had published the complete financial statements for the period of 2013 to 2017 on the website, in which the reporting period was from 2014 to 2016. (3) Foreign exchange and non-foreign exchange banks did not merge, were not in the acquisition and/or restructuring during the study period. Data collection technique used was documentation method that was by collecting data from the annual financial report of foreign exchange and non-foreign exchange banks of Indonesia that would be used in this research. Definition and measurement of research variables are shown in Table 1.

In Table 1, an explanation of the financial distress criteria is also expressed by Zaki et al. (2011) that the criteria of financial distress and non-financial distress in banking companies are: Code 1 is that the firm is experiencing financial distress. It is If the changes in equity value, changes in ROA value and changes in NIM value to a banking firm are below or equal to the median value of all observations. It is in the class of financial distress if it meets all three criteria above, if the three ratios of equity, ROA and NIM are below the median value of all observations. Code 0 is that the firm is not experiencing financial distress. If the changes in equity value, change of ROA value and change of NIM value in banking firm are above median value from all observation.

Table 1. Definition of Operational and Variable Measurement

\begin{tabular}{|c|c|c|}
\hline Variables & Definition & Measurement \\
\hline Financial Distress & $\begin{array}{l}\text { A condition in which the firm's finances are unhealthy or } \\
\text { in a crisis. firms that experience financial distress } \\
\text { condition is seen in the condition of financial statements } \\
\text { that show negative net income }\end{array}$ & $\begin{array}{l}\text { Dummy variable with binomial size, which is one (1) if } \\
\text { the company is experiencing financial distress; Zero } \\
\text { (0) if the company does not experience financial } \\
\text { distress }\end{array}$ \\
\hline \multirow[t]{6}{*}{ Bankometer Model } & Capital to Asset Ratio (CA) & $\mathrm{CA}=\frac{\text { Capital }}{\text { Total assets }}$ \\
\hline & Equity to Asset Ratio (EA) & $\mathrm{EA}=\frac{\text { Equity }}{\text { Total assets }}$ \\
\hline & Capital Adequacy Ratio (CAR) & $\mathrm{CAR}=\frac{\text { Tier1 capital }+ \text { Tier2 capital }}{\text { Risk weighted assets }}$ \\
\hline & Non-Performing Loan Ratio (NPL) & NPL $=\frac{\text { Non performing loan }}{\text { Total loan }}$ \\
\hline & Cost to Income Ratio (CIR) & $\mathrm{CIR}=\frac{\text { Operating expenses }}{\text { Operating income }}$ \\
\hline & Loans to Asset Ratio (LA) & $\mathrm{LA}=\frac{\text { Loans }}{\text { Total assets }}$ \\
\hline
\end{tabular}




\section{Jurnal Keuangan dan Perbankan | PERBANKAN}

Vol. 22, No. 2, April 2018: 373-379

The dependent variable used was Bankometer Model. To calculate the value in the Bankometer Model, to predict financial distress (Shar, Shah, \& Jamali, 2010):

$$
\begin{aligned}
\text { S-Score }= & 1.5(\mathrm{CA})+1.2(\mathrm{EA})+3.5(\mathrm{CAR})+0.6 \\
& (\mathrm{NPL})+0.3(\mathrm{CIR})+0.4(\mathrm{LA})
\end{aligned}
$$

Information:

$\begin{array}{ll}\text { CA } & \text { : Capital to Asset Ratio } \\ \text { EA } & \text { : Equity to Asset Ratio } \\ \text { CAR } & \text { : Capital Adequacy Ratio } \\ \text { NPL } & \text { : Non Performing Loan Ratio } \\ \text { CIR } & \text { : Cost to Income Ratio } \\ \text { LA } & \text { : Loans to Asset Ratio } \\ \text { S-Score } & \text { Score to assess bankruptcy or not go bank- } \\ & \text { rupt }\end{array}$

S-Score : If the value is $<50=$ Insolvent (bankrupt)

S-Score : If the value is $<70=$ Solvent (not bankrupt)

S-Score : If the value is $50<$ S-Score $<70=$ Gray Area, with criteria: $\mathrm{CA}>4 \%$; $\mathrm{EA}>2 \%$; CAR> $8 \%$; NPL $<15 \%$; CIR $<40 \%$ and LA $<65 \%$.

Hypotheses made in this research were:

$\mathrm{H}_{1}$ : Bankometer Model can be used to predict the condition of financial distress on foreign exchange bank

$\mathrm{H}_{2}$ : Bankometer Model can be used to predict the condition of financial distress in non-foreign exchange bank

\section{RESULTS}

Table 2 shows the result of Bankometer calculations on foreign exchange and non-foreign exchange banks, based on Bankometer Model formulation according to Shar, Shah, \& Jamali (2010). The result of this calculation was based on the average Bankometer value of the total number of banks used as the sample.
Table 2. Average Score of Bankometer at Foreign Exchange and Non-foreign exchange Banks

\begin{tabular}{lrrr}
\hline \multicolumn{1}{c}{ Information } & \multicolumn{1}{c}{$\mathbf{2 0 1 4}$} & \multicolumn{1}{c}{$\mathbf{2 0 1 5}$} & \multicolumn{1}{c}{$\mathbf{2 0 1 6}$} \\
\hline Overall Average & 103.9 & 105.1 & 87.5 \\
$\begin{array}{l}\text { Foreign Exchange Bank } \\
\begin{array}{l}\text { Non-Foreign Exchange } \\
\text { Bank }\end{array}\end{array}$ & 116.88 & 120.89 & 92.02 \\
\hline
\end{tabular}

Table 2 shows the average score of each Bankometer score in foreign exchange bank and non-foreign exchange bank between 2014 and 2016. Based on the criteria of Bankometer score previously described, the result in Table 2 explained that the average scores of Bankometer for foreign exchange banks were: in 2014, the score was 116.88, in 2015 it was 120.89, and in 2016 it was 90.02. Based on the scores, the foreign exchange bank from 2014 to 2016 was classified solvent because the score was $>70$. For non- foreign exchange bank, in 2014 the score was 88.6, in 2015 the score was 86.4, and in 2016 the score was 82.3. Based on the scores, nonforeign exchange bank from 2014 to 2016 was classified solvent because the score was $>70$. From both banks, if the scores owned by each bank were compared, non-foreign exchange bank tended to be close to 70. It meant that some banks belonged to the non-foreign exchange bank were more in an insolvent condition. Overall from 2014 to 2016, the average score of both banks indicated that both banks were an insolvent condition.

Table 3. Test Result of Foreign Exchange Bank Fit model

\begin{tabular}{lc}
\hline \multicolumn{1}{c}{ Fit Model Test } & Result \\
\hline-2 log Likelihood & 68.233 \\
Block 0 & 55.262 \\
Block 1 & \\
Snell R Square and Nagelkerke R Square & 0.187 \\
Cox and Snell R Square & 0.403 \\
Nagelkerke R Square & \\
Hosmer and Lemeshow's Goodness & \\
of Fit Test & 12.262 \\
Chi-Square & 0.055 \\
Significance & \\
Classification Table & 90.0 \\
Overall Percentage & \\
\hline
\end{tabular}


Based on Table 3, it is known for the value of -2 Log likelihood in the beginning without adding the independent variable in the model was 64.112 and after the independent variable was added into the regression model, the value of Log-2 likelihood (Block 1) at the end indicated that the value had changed to 55.262, so it was known that the value of -2 Log Likelihood had decreased in value. The conclusion was that the Logistic regression model used in this research had been Fit or by existing data.

Based on Table 3, it is known that the value for Cox and Snell R Square was 0.187 and the value of Nagelkerke R Square was 0.403 . The value described that the variability of the Financial Distress condition of the Foreign Exchange Bank in banking firm during the period 2014 to 2016, which could be described by the variability of the formulation of Bankometer Model was 0403 or $40 \%$, while the rest could be elaborated by other factors not included in the study. Chi-Square value was 12,262, and the significance value was 0.055 , in which the 0.055 was greater than $0.050(5 \%)$, so it could be concluded that the logistic regression model used in this study was feasible for further analysis. The value in the classification column was $90 \%$. It explained that the logistic regression model in this study had a fairly good accuracy to predict financial distress in foreign exchange banks.

Table 4. Test Result of Non-Foreign Exchange Fit Model

\begin{tabular}{lr}
\multicolumn{1}{c}{ Fit Model Test } & Result \\
\hline-2 log Likelihood & \\
Block 0 & 61003 \\
Block 1 & 52.130 \\
Snell R Square and Nagelkerke R Square & \\
Cox and Snell R Square & 0.127 \\
Nagelkerke R Square & 0.429 \\
Hosmer and Lemeshow's Goodness & \\
of Fit Test & \\
Chi-Square & 10.162 \\
Significance & 0.065 \\
Classification Table & \\
Overall Percentage & 88.0 \\
\hline
\end{tabular}

Based on Table 4, it is known that the value of -2 Log likelihood in the beginning (Block 0) without adding the independent variable in the model was 61.003, and after the independent variable was added to the regression model, the value of $-2 \mathrm{Log}$ likelihood at the end (Block 1) indicated the value had changed to 52,130. Thus, it is known that the value of -2 Log Likelihood had decreased in value. The conclusion was that the Logistic regression model used in this research had been Fit or in accordance with existing data.

Based on Table 4, it is known that the value of Cox and Snell R Square was 0.127 and the value of Nagelkerke R Square was 0.429. The value described the variability of the Financial Distress condition of Non-Foreign Exchange Bank in banking firm over the period 2014 to 2016, which could be explained by the variability of the formulation of Bankometer Model was 0.429 or $42.9 \%$, while the rest could be elaborated by other factors not included in the study. Chi-square value was10162 and the significance value was 0.065 , in which 0.065 was greater than $0.050(5 \%)$. Thus, it can be concluded that the logistic regression model used in this study was feasible for further analysis. The value in classification column was $88 \%$. The percentage explained that the logistic regression model in this study had a fairly good accuracy to predict financial distress in non-foreign exchange banks.

Table 5. Logistic Regression Result

\begin{tabular}{lcccc}
\hline \multicolumn{1}{c}{ Variable } & $\begin{array}{c}\text { Coefficient } \\
\text { (B) }\end{array}$ & Wald & Sig. & $\begin{array}{c}\text { Exp } \\
\text { (B) }\end{array}$ \\
\hline $\begin{array}{l}\text { Foreign } \\
\text { exchange }\end{array}$ & 0.046 & 3.364 & 0.048 & 0.873 \\
$\begin{array}{l}\text { Non-Foreign } \\
\text { Exchange }\end{array}$ & 0.057 & 5.471 & 0.025 & 0.728 \\
\hline
\end{tabular}

Based on Table 5, it can be seen that the significance value for foreign exchange bank was 0.048 , in which 0.048 was smaller than $0.050(5 \%)$, and the significance value for non- foreign exchange bank was 0.025 , in which 0.025 was less than $0.050(5 \%)$. Each regression analysis result showed a number 


\section{Jurnal Keuangan dan Perbankan | PERBANKAN}

Vol. 22, No. 2, April 2018: 373-379

below significance level of 0.05 . It can be concluded that hypothesis 1 and hypothesis 2 were accepted, and it meant that Bankometer Model could be used to predict financial distress condition on foreign exchange and non-foreign exchange banks.

\section{DISCUSSION}

Based on the results of the study, it could be concluded that both hypotheses were accepted which meant that the Bankometer Model could be used to predict financial distress in foreign exchange and non-foreign exchange banks in Indonesia. Financial distress is a condition in which the firm's finances are unhealthy or in crisis. Therefore the use of a model to determine whether the condition of the firm is classified as financial distress or not financial distress must be relevant to the type of firms under study. Theoretically Bankometer Model can be used to predict financial distress in foreign exchange and non-foreign exchange banks in Indonesia because the model uses variables from the financial statements of a banking firm such as CA (Capital to Asset Ratio) which is used to measure the liquidity level of total assets and capital position, EA (Equity to Asset Ratio) which is used to measure the amount of capital that is owned that is used to fund all assets of the firm, CAR (Capital Adequacy Ratio) which is used to measure the ability of banks in providing funds which are used to overcome the possibility of risk reactions, NPL (Non- Performing Loan) which is used to measure the level of non-performing loans in the banking firm, CIR (Cost to Income Ratio) which is used to measure the level of bank efficiency in performing its activities by comparing total costs with revenues and LA (Loans to Asset Ratio) that is used to measure the ability of banks to meet the demand for credit by using total assets owned.

The results of previous research conducted by Laila \& Widihadnanto (2017) indicated that the use of Bankometer Model could be used in predicting financial distress between Syariah banking and con- ventional banking firm, and research result of Budiman, Herwany, \& Kristanti (2017) indicated that Bankometer Model could be used in determining the condition of financial distress at Syariah bank. There are differences in previous research with current research. There is a similarity in term of the use of the model in determining the financial distress that is Bankometer Model. The previous research difference from the current research is in the type of banking firms studied. The research of Laila \& Widihadnanto (2017) used Syariah and conventional banking, and the research of Budiman, Herwany, \& Kristanti (2017) used Syariah banking firms, while this study used foreign exchange and non-foreign exchange banks.

This study illustrated that Bankometer Model could be used to predict financial distress in foreign exchange and non-foreign exchange banks, and this research provided novelty findings on the use of the latest model namely Bankometer Model that could be applied to foreign exchange and non-foreign exchange banks.

\section{CONCLUSION AND SUGGESTIONS}

\section{Conclusion}

This study illustrates that Bankometer Model can be used to predict financial distress in foreign exchange and non-foreign exchange banks. Theoretically, this research can provide an accurate study on the selection of Bankometer Model to determine the prediction of financial distress. Practically, this research can be used as a reference for banking firms to use Bankometer Model in predicting and analyzing bankruptcy level of the bank, so that the firms can avoid a condition that leads into bankruptcy condition.

\section{Suggestions}

The suggestions that can be given to further researchers are extending the study period and expanding the sample research. The suggestion for 


\title{
Bankometer Models for Predicting Financial Distress in Banking Industry
}

\author{
Laely Aghe Africa
}

the management of foreign exchange and non-foreign exchange banks is by increasing the vigilance to avoid financial distress conditions by making a system of assessment on the condition of the bank by using Bankometer Model.

\section{REFERENCES}

Africa, L. A. (2016). Financial distress for bankruptcy early warning by the risk analysis on go public in Indonesia. Journal of Economics and Accountancy Ventura, 19(2), 155-166.

Arulvel, K. K., \& Balaputhiran, S. (2013). Financial position of banking sector: A comparative study between state and private sector banks in Sri Lanka. Academicia: An International Multidisciplinary Research Journal, 3(2), 212-221.

Almilia, L. S., \& Kristijadi, E. (2003). Analisis rasio keuangan untuk memprediksi kondisi financial distress perusahaan manufaktur yang terdaftar di Bursa Efek Jakarta. Jurnal Akuntansi dan Auditing Indonesia, 7(2), 183208.

Budiman, T., Herwany, A., \& Kristanti, F. T (2017). An evaluation of financial distress for Islamic banks in Indonesia using a Bankometer Model. Journal of Finance and Banking Review, 2(3), 14-20.

Erari, A. D. (2013). Financial performance analysis of PT. Bank Papua: Application of CAEL, Z-Score, and Bankometer. IOSR Journal of Business and Management, 7(5), 08-16
Fatmawati, M. (2012). Penggunaan the Zmijewski Model, the Altman Model, dan theSpringate Model sebagai prediktor delisting. Jurnal Keuangan dan Perbankan, 16(1), 56-65

Fayed, M. E. (2013). Comparative performance study of conventional and Islamic banking in Egypt. Journal of Applied Finance and Banking, 3(2), 1-14.

Gunawan, B., Pamungkas, R., \& Susilawati, D. (2017). Perbandingan prediksi financial distress dengan model Altman, Grover dan Zmijewski. Jurnal Akuntansi dan Investasi, 18(1), 119-127.

Hanif, D., Tariq, M., Tahir, A., \& Momeneen, W. U. (2012). Comparative performance study of conventional and Islamic banking in Pakistan. International Research Journal of Finance $\mathcal{E}$ Economics, 83, 61-73.

Husein, M. F., \& Pambekti, G. T. (2014). Precision of the Models of Altman, Springate, Zmijewski, and Grover for Predicting the financial distress. Journal of Economics, Business and Accountancy Ventura, 17(3).

Laila, N. \& Widihadnanto, F. (2017). Financial distress prediction using Bankometer Model on Islamic conventional banks:
Evidence from Indonesia. International Journal of Economics and Management, 11(1), 169-181.

Kurniawati, L., \& Kholis, N. (2015). Analisis model prediksi financial distress pada perusahaan perbankan syariah di indonesia. The $3^{\text {rd }}$ Call for Syariah Paper Accounting. Universitas Muhammadiyah Surakarta.

Nimalathasan, B., Balaputhiran S., \& Priya K. (2012). Evaluating the financial soundness of selected commercial banks in Srilanka: An application of Bankometer Model. International Journal of Research in Commerce \& Management, 3(1), 12-34.

Popovska, J. (2014). Modeling financial stability: The case of the banking sector in Macedonia. Journal of Applied Economics and Business, 2(1), 68-91

Samanhyia, S., Oware, K. M., \& Anisom-Yaansah, F., 2016. Financial distress and bankruptcy prediction: Evidence from Ghana. Expert Journal of Finance, 4, 52-65.

Shar, A. H., Shah, M. A., \& Jamali, H. (2010). Performance evaluation of banking sector in Pakistan: An application of bankometer. International Journal of Business and Management, 5(9), 81. 
